\title{
Variability and Genetic Diversity of Bottle Gourd [Lagenaria siceraria (mol.) Stand.] in Bangladesh
}

\author{
A. K. M. Quamruzzaman (Corresponding Author) \\ Olericulture Division, Horticulture Research Center, Bangladesh Agricultural Research \\ Institute, Joydebpur, Gazipur-1701, Bangladesh \\ Email: akmqzs@gmail.com \\ F. Islam \\ Olericulture Division, Horticulture Research Center, Bangladesh Agricultural Research \\ Institute, Joydebpur, Gazipur-1701, Bangladesh \\ Email: ive_bari@yahoo.com
}

M. M. R. Salim

Olericulture Division, Horticulture Research Center, Bangladesh Agricultural Research Institute, Joydebpur, Gazipur-1701, Bangladesh

Email: msalim.hrc@gmail.com

L. Akhter

Olericulture Division, Horticulture Research Center, Bangladesh Agricultural Research Institute, Joydebpur, Gazipur-1701, Bangladesh

Email: limuakter@gmail.com

M. M. Rahman

Bangladesh Agricultural Research Council, Farmgate, Dhaka-1207

Email: m.rahman6820@yahoo.com

M. A. Z. Chowdhury 
Bangladesh Agricultural Research Council, Farmgate, Dhaka-1207

Email: zilani71@gmail.com

Received: May 29, 2020 Accepted: June 22, 2020

doi:10.5296/jbls.v11i2.17322 URL: https://doi.org/10.5296/jbls.v11i2.17322

\begin{abstract}
The presented study was conducted at the experimental field of Olericulture Division, Horticulture Research Center, Bangladesh Agricultural Research Institute, Gazipur, Bangladesh during the year 2018-19 to assess the extent of genetic diversity among 25 bottle gourd germplasms. Data on: days to first harvest, fruit number per plant, average fruit weight, fruit yield (kg/plant), fruit length, fruit diameter, fruit yield (t/ha), fruit shape and fruit color were recorded. Plot means for quantitative characters were used for the statistical analysis, while genetic diversity, principal component analysis (PCA), principal Coordinate analysis (PCO), cluster analysis, cluster means and two-dimensional scattered plotting diagram were studied. The germplasms were constellated into five distinct groups with the range of 3 germplasms in the cluster III to 6 germplasms in the clusters II and IV. The inter-cluster distance in all cases was larger than is the intra-cluster distance. The highest intra-cluster value (2.65) was found in the cluster IV. Maximal inter-cluster distance (12.24) was observed between germplasm of cluster I and V, followed by the clusters I and III (12.05) and minimal was found between germplasms of cluster I and IV (3.46). In case of the cluster means values and yield contributing performance cluster I, cluster IV and cluster III performed well. Considering the group distance and inter-genotypic crosses between the clusters and cluster means, inbreeds belong to clusters: I, IV and III, to that will be given higher priority for crossing in future bottle gourd hybridization program.
\end{abstract}

Keywords: Genetic divergence, principal component analysis (PCA), principal Coordinate analysis (PCO), cluster analysis, cluster means, two -dimensional scattered plotting diagram, bottle gourd, Bangladesh

\title{
1. Introduction
}

Bottle gourd [Lagenaria siceraria (Mol.) Stand.] is a very popular winter vegetable in Bangladesh. It belongs to the family Cucurbitaceae. The cultivated species is commonly known as bottle gourd or white flowered gourd. Bottle gourd is a cross pollinated crop with large amount of variation for many economically important traits. Bangladesh is one of the Centre's of diversity of bottle gourd endowed with a variety of diverse germplasm (Sultana et al., 2018). The climatic condition of winter in Bangladesh favors better growth and yield of bottle gourd, but hot and humid summer and summer rainy season gives considerable yield. The average day temperature of $20-27^{\circ} \mathrm{C}$ with lower night temperature of $18-23^{\circ} \mathrm{C}$ is optimal for growth and fruiting. In Bangladesh the average yield of 11.81 tons per hectare (Anon., 
2017), which is very low. Its cultivation and uses are wide in winter season but now it is cultivating during summer and rainy season. Bottle gourd is widely cultivated throughout the country. It is found to cultivate in commercial way in the field as well as homestead in rural Bangladesh. Significant variation of plant type, fruit type, fruit shape, fruit's color was found among the different genotypes.

It is necessary to select suitable parental lines from available indigenous germplasms, to carry out any successful breeding program. The study of genetic divergence is a popular method in parent selection for researchers involved in breeding programs of several crops, leading to reduce the number of crosses (Guerra et al. 1999). The progenies derived from diverse parents are expected to show a broad spectrum of genetic variability and provide better scope to isolate a superior recombinants. Therefore, genetically diverse genotypes should be used in a hybridization program to get a superior recombinants. The multivariate analysis is the most widely used statistical tools to quantify the genetic divergence. Among the various methods developed to study the genetic divergence in the genotypes/accessions, the Mahalanobis $\mathrm{D}^{2}$ (Mahalanobis, 1936) is the most reliable and widely used statistical tools to quantify the degree of genetic divergence by assessing the relative contribution of different characters to the total divergence. It is a very useful technique and has been used by several workers in case of self-pollinated or cross pollinated crops (Bashar et al., 2016; Hasan et al., 2015; Huque et al., 2012; Natarajan et al., 1988; Shidhu et al., 1989). The relative contribution of different traits to the total divergence helps to select a particular trait or a combination of traits for inter-crossing which avoids wastage to time and labor. Principal component analysis (PCA) is also a powerful technique which allows the visualization of natural grouping of the genotypes and is precise indicator of differences among genotypes (Huque et al., 2012). More stable genotypes are believed to generate a superior recombinants through crossing as there is less environmental influence on them. Keeping all these points in mind, the present investigation was undertaken to evaluate the genetic diversity among the bottle gourd genotypes collected from diverse locations and to identify a superior genotypes for future use.

\section{Research Methods}

\subsection{Experimental Site}

The experiment was conducted at the Olericulture Division of Horticulture Research Centre (HRC), Bangladesh Agricultural Research Institute (BARI) during 2018-19 with 25 germplasm of bottle gourd. The experimental field was at $23.9920^{\circ} \mathrm{N}$ Latitude and $90.4125^{\circ}$ E Longitudes having an elevation of $8.2 \mathrm{~m}$ from sea level.

\subsection{Plant Materials}

The seeds of these germplasm were sown on the seedbed on 05 September, 2018. Fifteen days old seedlings were transplanted in the main field on 20 September, 2018.

\subsection{Experimental Design and Layout}

The experiment was laid out in a Randomized Complete Block design with three replications. The unit plot size was $10.0 \times 2.0 \mathrm{~m}$ maintaining $2.0 \times 2.5 \mathrm{~m}$ spacing and $0.5 \mathrm{~m}$ drain. 


\subsection{Land Fertilization}

The land was fertilized with organic fertilizer, N, P, K, S, B and Zn @ 3000, 80, 45, 88, 25, 1.8 and $4.5 \mathrm{~kg} / \mathrm{ha}$, respectively. Half of organic fertilizer and all of S, Zn and B each of P and K @ $30 \mathrm{~kg} / \mathrm{ha}$ were applied during final land preparation. Rest of organic fertilizer and P and K @ $15 \mathrm{~kg} / \mathrm{ha}$ were applied as basal in pit. Rest of $\mathrm{N}$ and $\mathrm{K}$ were applied after 20 days of transplanting in 4 equal installments at 20 days interval starting. The intercultural operations (weeding and irrigation etc.) were done as and when necessary.

\subsection{Data Recorded}

Data on days to first harvest, fruit number/ plant, average fruit weight $(\mathrm{kg})$, fruit yield $(\mathrm{kg} /$ plant), fruit length $(\mathrm{cm})$, fruit diameter $(\mathrm{cm})$, fruit yield $(\mathrm{t} / \mathrm{ha})$, fruit shape and fruit's colour were recorded from three randomly selected plants per plot.

\subsection{Statistical and Biometrical Analysis}

Plot means for 7 quantitative characters were used for the statistical analysis. Genetic diversity was studied following Mahalanobis's (1936) generalized distance ( $\mathrm{D}^{2}$ ) extended by Rao (1952). Based on the $\mathrm{D}^{2}$ values, the germplasm was grouped into clusters following the method suggested by Tocher (Rao, 1952). Genetic diversity was studied following Mahalanobis's (1936) generalized distance $\left(\mathrm{D}^{2}\right)$ extended by Rao (1952). Statistical analyses were carried out using GenStat 5 software.

\section{Results and Discussion}

\subsection{Distribution of Bottle Gourd Germplasm}

The analysis of variance showed significant differences between the germplasms for all the characters studied indicated the presence of sufficient variability in the germplasm. Based on the degree of divergence 25 germplasms were grouped into five clusters (Table 1). The distribution pattern revealed that maximal number of germplasms (6) was included in cluster II and IV, while cluster III included the minimal (3) germplasms. 
Table 1. Distribution of 25 germplasm of bottle gourd in different clusters

\begin{tabular}{|c|c|c|c|c|c|}
\hline Clusters & $\begin{array}{c}\text { Number of } \\
\text { germplasm/ cluster }\end{array}$ & $\begin{array}{l}\text { Code no. of } \\
\text { germplasm }\end{array}$ & Germplasm & Fruit shape & Fruit colour \\
\hline \multirow[t]{5}{*}{ I } & 5 & 1 & LS172 & Bottle & Light green \\
\hline & & 4 & LS175 & Bottle & Deep Green \\
\hline & & 7 & LS178 & Bottle & Light green \\
\hline & & 10 & LS181 & Bottle & Light green \\
\hline & & 15 & LS187 & Balloon & Deep Green + white spot \\
\hline \multirow[t]{6}{*}{ II } & 6 & 6 & LS177 & Oval & Light green \\
\hline & & 8 & LS179 & Bottle & Deep Green + white spot \\
\hline & & 9 & LS180 & Bottle & Deep Green + white spot \\
\hline & & 11 & LS182 & Bottle & Light green \\
\hline & & 16 & LS188 & Bottle & Green + white spot \\
\hline & & 23 & LS196 & Cylindrical & Light Green \\
\hline \multirow[t]{3}{*}{ III } & 3 & 13 & LS184 & Bottle & Green + white spot \\
\hline & & 20 & LS192 & Bottle & Green + white spot \\
\hline & & 22 & LS195 & Cylindrical & Light Green \\
\hline \multirow[t]{6}{*}{ IV } & 6 & 2 & LS173 & Cylindrical & Deep Green + white spot \\
\hline & & 3 & LS174 & Oval & Deep Green + white spot \\
\hline & & 5 & LS176 & Round & Light green \\
\hline & & 12 & LS183 & Oblong & Deep Green + white spot \\
\hline & & 14 & LS186 & Oblong & Green \\
\hline & & 25 & BARI Lau-4 & Bottle & Green + white spot \\
\hline \multirow[t]{5}{*}{$\mathrm{V}$} & 5 & 17 & LS189 & Bottle & Green + white spot \\
\hline & & 18 & LS190 & Cylindrical & Green + white spot \\
\hline & & 19 & LS191 & Cylindrical & Green + white spot \\
\hline & & 21 & LS193 & Cylindrical & Green + white spot \\
\hline & & 24 & LS198 & Round & Light Green \\
\hline
\end{tabular}

\subsection{Principal Component Analysis (PCA)}

Seven characters were considered for genetic diversity analysis. Eigen values of seven principal axes and percentage of total variation accounting for them obtained from the principal component analysis are presented in Table 2 . The results revealed that the first principal axis largely accounted for the variation among the genotypes which alone contributed to $61.87 \%$ of the variations. This is followed by the $2^{\text {nd }}$ axis $(30.80 \%)$ while the first five Eigen values for the principal component axes of genotype accounted for $100.00 \%$ of the total variation among 7 characters describing 23 genotypes while the former two accounted for $92.67 \%$.

Table 2. Latent roots (Eigen values) and percent of variation in respect of 7 characters in bottle gourd

\begin{tabular}{llccc}
\hline $\begin{array}{l}\text { Sl. } \\
\text { No. }\end{array}$ & \multicolumn{1}{c}{ Principal component axis } & Latent roots & $\begin{array}{c}\text { \% of total variation } \\
\text { accounted for }\end{array}$ & $\begin{array}{c}\text { Cumulative } \\
\text { percent }\end{array}$ \\
\hline 1. & Days to $1^{\text {st }}$ Harvest & 10.177 & 61.87 & 61.87 \\
2. & No. of Fruit/plant & 1.062 & 30.80 & 92.67 \\
3. & Yield /plant $(\mathrm{kg})$ & 0.360 & 6.79 & 99.46 \\
4. & Average Fruit Wt. $(\mathrm{kg})$ & 0.285 & 0.34 & 99.80 \\
5. & Fruit length $(\mathrm{cm})$ & 0.067 & 0.21 & 100.00 \\
6. & Fruit Diameter $(\mathrm{cm})$ & 0.001 & 0.00 & 100.00 \\
7. & Yield (t/ha) & 0.00 & 0.00 & 100.00 \\
\hline
\end{tabular}




\section{Macrothink}

\subsection{Principal Coordinate Analysis (PCO)}

Principal Coordinate analysis (PCO) was done to get inter genotypic distances. The highest inter genotypic distance (2.4565) was observed between the genotypes LS178 and LS189 followed by the genotypes LS176 and LS189 (2.1833) and genotypes LS178 and LS190 (2.1661) (Table 3). The difference between the highest inter genotypic distance indicated the existence of variability among the 25 genotypes of bottle gourd. Sukhija et al. (1982) while analyzing 46 lines of water melon found that the $\mathrm{D}^{2}$ values ranged from 3.84 to 308.43 showing high divergence among different lines. Hasan et al. (2000) and Rahman et al. (2000) obtained a range of 2.001 to 7.72 and 4.87 to $19.989 \mathrm{D}^{2}$ values in Yam and Chili.

Table 3. Ten of higher inter-genotypic distance between pair of 25 bottle gourd genotypes

\begin{tabular}{ll}
\hline 10 higher $D^{2}$ values & Genotype combination \\
\hline 2.4565 & LS178 and LS189 \\
2.1833 & LS176 and LS189 \\
2.1661 & LS178 and LS190 \\
2.1276 & LS172 and LS189 and LS198 \\
2.0976 & LS182 and LS189 \\
2.0574 & LS188 and LS189 \\
2.0494 & LS176 and LS190 \\
1.8628 & LS172 and LS190 \\
1.8233 & LS176 and LS198 \\
1.8086 &
\end{tabular}

\subsection{Cluster Analysis}

On the basis of Mahalanobis D2 values, the 25 genotypes were grouped into five divergent clusters (Table 1), indicating an adequate genetic diversity for selecting superior and diverse parents which can be further exploited for any breeding program. Cluster II [LS177, LS179, LS180, LS182, LS188, LS196] and cluster IV [LS173, LS174, LS176, LS183, LS186, BARI Lau-4] were the largest group containing 6 genotypes each, followed by cluster I [LS172, LS175, LS178, LS181, LS187] and cluster V [LS189, LS190, LS191, LS193, LS198] containing 5 genotypes each, while cluster III had only 3 genotypes [LS184, LS192, LS195]. Similar result was found by Indra et al. (2000), Sreelathakumary and Rajmony (2004), 


\section{I Macrothink}

Farhad et al. (2010), Datta and Jana (2011), Datta and Das (2013) and Yatung et al. (2014).

The inter cluster distances in all of the cases were larger than the intra cluster distances, so indicating wider diversity among the germplasm of the distant group (Table 4). The intra cluster distance was maximal in cluster IV (2.65) and minimal in cluster III (1.17) indicating the germplasm in cluster IV were more heterogeneous and those in cluster III were closely related. The range of the intra cluster distance values indicated homogeneous nature of the germplasm within the clusters. Regarding inter cluster distance, cluster I showed maximal genetic distance with cluster V (12.24) followed by the genetic distance from cluster I and III (12.05) suggesting wide diversity between them. The moderate distances were observed among the cluster I and IV (7.78) and cluster III and IV (6.42) suggesting moderate diversity exist between them and the minimal distance was found between the germplasms of cluster I and IV (3.46). The result was supported by scatter diagram (Fig 1).

Table 4. Mean intra (bold) and inter cluster distances $\left(\mathrm{D}^{2}\right)$ for the 25 bottle gourd germplasm obtained on the basis of the 7 morphological characters

\begin{tabular}{lccccc}
\hline Clusters & I & II & III & IV & V \\
\hline I & $\mathbf{1 . 8 8}$ & 9.07 & 12.05 & 7.78 & 12.24 \\
II & & $\mathbf{2 . 0 5}$ & 5.25 & 3.46 & 4.24 \\
III & & $\mathbf{1 . 1 7}$ & 6.42 & 3.81 \\
IV & & & $\mathbf{2 . 6 5}$ & 5.61 \\
V & & & & $\mathbf{2 . 2 2}$ \\
\hline
\end{tabular}

\subsection{Cluster Means}

Differences in cluster means existed for all the characters (Table 5). Cluster I had five germplasms and recorded the highest mean for number of fruit/plant (13.60), fruit yield /plant $(24.72 \mathrm{~kg})$, fruit yield (49.44 t/ha) and second lowest mean for days to $1^{\text {st }}$ harvest $(79.20)$. Cluster II was constituted of six germplasms and exhibited no highest mean value for any characters. Cluster III had three germplasms and was responsible for lowest mean for days to $1^{\text {st }}$ harvest (70.00), while second lowest vales for average fruit weight $(1.83 \mathrm{~kg})$, fruit diameter $(12.23 \mathrm{~cm})$. Cluster IV was constituted of six germplasms and exhibited highest mean value for average fruit weight $(2.07 \mathrm{~kg})$, fruit length $(39.50 \mathrm{~cm})$, while cluster $\mathrm{V}$ was constituted of five germplasm and exhibited highest mean value for fruit diameter $(12.24 \mathrm{~cm})$. So, Quamruzzaman, 2020 and Jagadev et al. (1991) reported that the characters contributing the maximal to the divergence should be given greater emphasis for deciding the type of cluster for the purpose of further selection and the choice of parents for hybridization. 
Table 5. Cluster means for twelve characters in 25 bottle gourd germplasm

\begin{tabular}{lccccc}
\hline Characters & Cluster I & Cluster II & Cluster III & Cluster IV & Cluster V \\
\hline Days to $1^{\text {st }}$ harvest & 79.20 & 96.50 & 70.00 & 86.83 & 88.40 \\
Number of fruit/plant & 13.60 & 6.83 & 5.33 & 7.88 & 5.00 \\
Average fruit weight (kg) & 1.82 & 1.80 & 1.83 & 2.07 & 1.72 \\
Fruit yield /plant (kg) & 24.72 & 12.20 & 9.70 & 16.20 & 8.52 \\
Fruit length (cm) & 39.20 & 35.83 & 24.67 & 39.50 & 26.40 \\
Fruit diameter (cm) & 10.10 & 10.27 & 12.23 & 10.58 & 12.24 \\
Fruit yield (t/ha) & 49.44 & 24.40 & 19.40 & 32.40 & 16.98 \\
\hline
\end{tabular}

Based on principal component axes I and II, a two -dimensional scattered plotting diagram $\left(\mathrm{Z}_{1}\right.$ and $\mathrm{Z}_{2}$ ) reflecting the position of germplasm are presented in Fig. 1. It was revealed that from the diagram there were mainly five clusters. Most distantly located germplasm was within cluster I [LS172, LS175, LS178, LS181, LS187] and cluster V [LS189, LS190, LS191, LS193, LS198] as well as cluster I [LS172, LS175, LS178, LS181, LS187] and cluster III [LS184, LS192, LS195]. Distribution pattern of germplasm in the scattered diagram also revealed that considerable variability exists in the germplasm studied. 


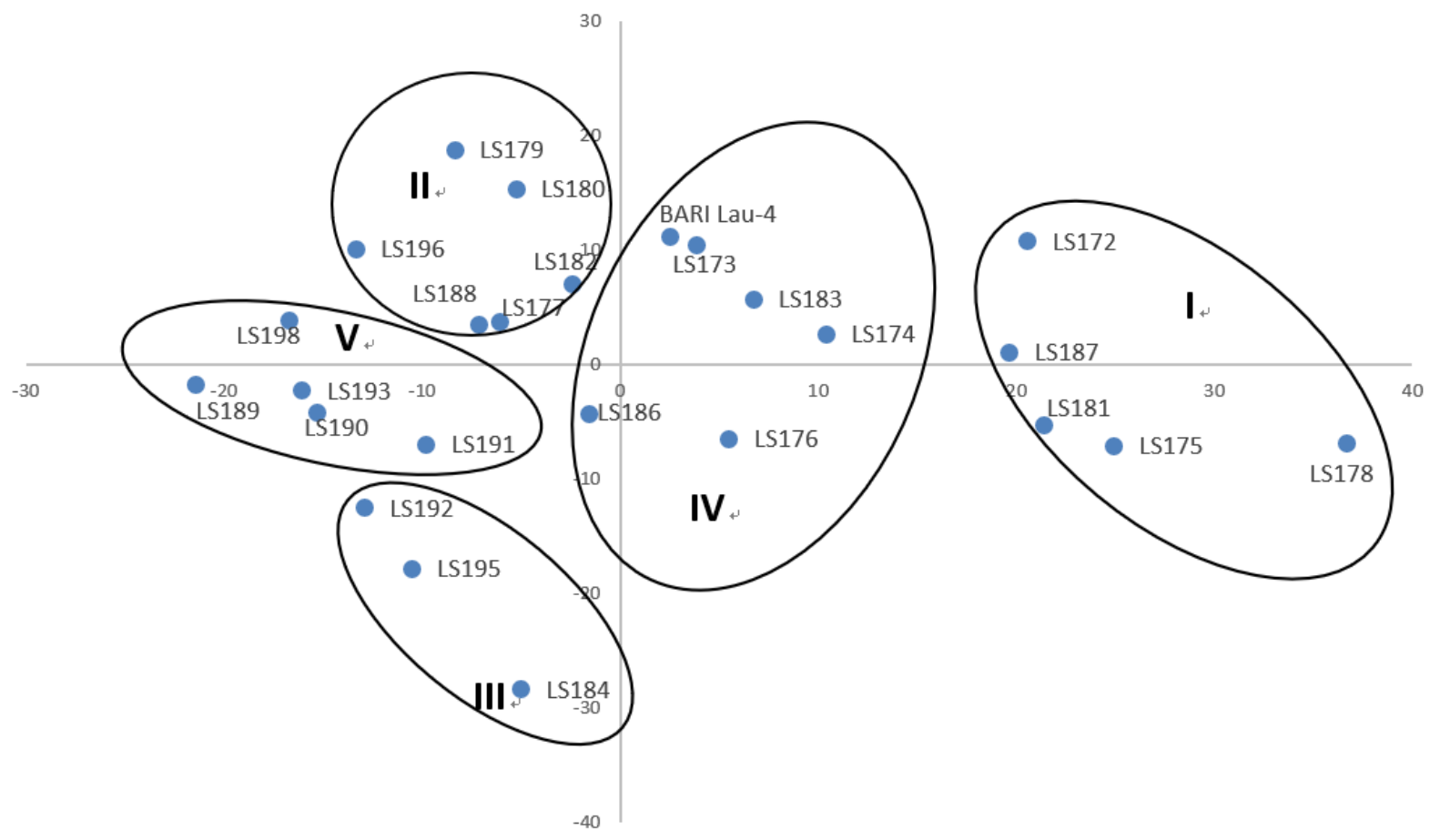

Figure 1. Distribution of 25 bottle gourd germplasm in a two-dimensional scatter diagram based on PCA scores superimposed with clusters

Contributions of the characters towards divergence are presented in Table 6. The canonical analysis revealed that, values in both vectors (Vector I and II) for number of fruit/plant (1.4742 and 0.2523 ) were positive. Such results indicated that this character contributed maximal towards divergence of the germplasm. It is interesting to note that the greater divergence among the materials in the present study due to number of fruit/plant will offer a good scope for improvement of yield through rational selection of parents for producing heterotic bottle gourd hybrids. The major contribution of this character to divergence was well confirmed by their cluster mean; where the ranges varied indicating the major role of this character as differentiate at inter cluster level. The cluster means for number of fruit/ plant were 13.60 for Cluster I and 7.88 for Cluster IV showed significant difference. Quamruzzaman et al. (2008b) reported that days to 1st female flower open, fruit diameter, single fruit weight and fruits per plant contributing major portion of the total genetic diversity in ridge gourd. In other study Quamruzzaman et al. (2008a) reported fruits per plant and fruit yield per plant contribute towards divergence in bitter gourd. Masud et al. (1995) found that number of fruits per plant and yield per plant was one of the important contributors to genetic divergence in pumpkin. Hence, these characters could offer a scope for genetic improvement and deserve to be included as selection criteria in bottle gourd. 
Table 6. Latent vectors for seven quantitative characters of 25 germplasm of bottle gourd

\begin{tabular}{lcc}
\hline Characteristics & Vector $\left(\mathrm{Z}_{1}\right)$ & Vector $\left(\mathrm{Z}_{2}\right)$ \\
\hline Days to $1^{\text {st }}$ harvest & 0.034 & -0.0957 \\
Number of fruit/plant & 1.4742 & 0.2523 \\
Fruit yield /plant $(\mathrm{kg})$ & 3.1419 & -4.8461 \\
Average fruit weight $(\mathrm{kg})$ & -0.0287 & 0.1397 \\
Fruit length (cm) & -0.0574 & -0.1905 \\
Fruit diameter $(\mathrm{cm})$ & -0.5581 & -0.0586 \\
Fruit yield (t/ha) & -0.0135 & 0.07 \\
\hline
\end{tabular}

\section{Conclusion}

Usually the crosses are associated with the parents, which are included in the most distant clusters, are expected to give maximal heterosis and so create a wide variability in different and genetic architectures. However, for a practical plant breeder, the objective is not only to achieve high heterosis, but also to achieve high levels of production in the shortest possible time. Considering the group distance cluster I showed maximal genetic distance with cluster $\mathrm{V}$ (12.24) followed by the genetic distance from cluster I and III (12.05) suggesting wide diversity, so inter-genotypic crosses between the members of cluster I and V and cluster I and III would exhibit high heterosis and is also likely to produce new recombinations with desired traits. In case of the cluster means values and yield contributing performance cluster I, IV and III performed well. Therefore, inbreeds belong to cluster I, cluster IV and cluster III will be given higher priority for crossing in future bottle gourd hybridization program.

\section{Acknowledgment}

The author would like to thank the Olericulture Division, Horticulture Research Center, Bangladesh Agricultural Research Institute, Joydebpur, Gazipur-1701, Bangladesh for their financial support and research facilities.

\section{References}

Anonymous (2017). Year Book of Agricultural Statistics of Bangladesh 2016. Bangladesh Bureau of Statistics, Ministry of Planning, Government of Peoples Republic of Bangladesh, Dhaka, Bangladesh. pp. 249-290.

Bashar, A., Hossain, M. K., Hasan, R., Islam, S., Huque, A. K. M. M., \& Alam, N. (2016). Breeding potential of common eggplant (Solanum melongena L.) using divergence analysis. 
Bangladesh Journal of Botany, 45(1), 109-115.

Datta, S., \& Das, L. (2013). Characterization and genetic variability analysis in Capsicum annuum L. germplasm. SAARC Journal of Agriculture, 11(1), 91-103. https://doi.org/10.3329/sja.v11i1.18387

Datta, S., \& Jana, J. C. (2011). Studies on genetic divergence in chilli (Capsicum spp.) under sub Himalayan tracts of West Bengal. Journal of Crop and Weed, 7(1), 44-48.

Farhad, M. I., Hasanuzzaman, M., Biswas, B. K., Arifuzzaman, M., \& Islam, M. M. (2010). Genetic divergence in chilli (Capsicum annuum L.). Bangladesh Research Publications Journal, 3(3), 1998-2003.

Guerra, E. P., Destro, D., Miranda, L. A., \& Montalván, R. (1999). Parent selection for intercrossing in food type soybean through multivariate genetic divergence. Acta Scientiarum Agronomy, 21(3), 429-437.

Hasan, R., Huque, A. K. M. M., Hossain, M. K., \& Alam, N. (2015). Assessment of genetic divergence in Chilli (Capsicum annuum L.) genotypes. Plant Gene Trait, 6(3), 1-5.

Indra, P., Peter, K. V., \& Unnithan, V. K. G. (2000). Divergence in chilli. Spice India, 13(4), 15-20.

Jagadev, P. N., Shamal, K. M., \& Lenka, L. (1991). Genetic divergence in rape mustard. Indian J. Genet. Pl. Breed., 51, 465-466.

Mahalanobis P. C. (1936). On the generalized distance in statistics. Proceedings of the National Institute of Sciences of India, 2, 49-55.

Masud. M. A. T., Chowdhury, M. A. Z., Hossain, M. A., \& Hossain, S. M. M. (1995). Multivariate analysis in pumpkin (Cucurbita moschata Dueh ex Poir). Bangladesh Journalof Plant Breedingand Genetics, 8(1\&2), 45-50.

Quamruzzaman, A. K. M. (2020). Genetic Divergence in Bottle Gourd [Lagenaria siceraria (Mol.) Stand.]. Journal of Advances in Molecular Biology, 4(1), https://doi.org/10.22606/jamb.2020.41001

Quamruzzaman, A. K. M., Rahman, M. H, Nazrul Islam, Md, Rahman, S. M. L., \& Sarker, B. C. (2008b). Genetic diversity in land races of ridge gourd. Bangladesh Res. Pub. J. 1(1), 5-8.

Quamruzzaman, A. K. M., Rashid, M. A, Ali, M. M, Alam, A. K. M. M., \& Mashiur, R. M. (2008a). Genetic diversity in bitter gourd (Momordica charantia L.). Bangladesh J. Agril. Res., 33(1), 129-134.

Rao, C. R. (1952). Advanced Statistical Method in Biometrics Research. John wiley and sons, New York. p. 390.

Shidhu, J. S., Ahmed, S., Sing, M. P., \& Sing, P. K. (1989). Multivariate analysis in blackgram (Vigna mungo L.). Legume Research, 12(1), 35-37.

Sreelathakumary, I., \& Rajmony, L. (2004). Genetic divergence in chilli (Capsicum annuum 
L.). Indian Journal of Horticulture, 61(2), 137-139.

Sultana, S., Rahman, M., Ferdous, J., Ahamed, F., \& Chowdhury, A. (2018). Studies on genetic variability and interrelationship in bottle gourd [Lagenaria siceraria (Mol.) Standl]. International Journal of Agricultural Research, Innovation and Technology, 8(1), 14-17. https://doi.org/10.3329/ijarit.v8i1.38224

Yatung, T., Dubey, R. K., Singh, V., \& Upadhyay, G. (2014). Genetic diversity of chilli (Capsicum annuum L.) genotypes of India based on morpho-chemical traits. Australian Journal of Crop Science, 8(1), 97-102.

\section{Copyright Disclaimer}

Copyright for this article is retained by the author(s), with first publication rights granted to the journal.

This is an open-access article distributed under the terms and conditions of the Creative Commons Attribution license (http://creativecommons.org/licenses/by/4.0/). 